\title{
Yaşanmış Bakım Hikâyelerinde İz Bırakan Eylemler: Analitik ve Yansıtıcı Bir Yaklaşım
}

\section{Tracer Actions in Truelife Care Stories: An Analytic and Reflective Approach}

(Derleme)

\author{
Fadime Gamze TEKIN*, Emine $\mathrm{KOL}^{* *}$, Illkay BOZ***
}

\section{ÖZ}

Bakım sürekli gelişim gösteren dinamik bir kavramdır. Teorik bir terim olan bakım kavramı klinikte bakım gereksinimi olan birey ile karşılaşma ve ilişki kurma ile anlam kazanır. Bakım ancak hemşirenin bireyin yaşam alanına ve varoluşsal alanına girmesiyle başlayabilir ve böylece hemşire bireyin varoluş durumunu saptar, bunu hisseder ve tepki gösterir. Kişilerarası bakım ilişkisinde gerçekleştirilen her bir bakım davranışı bireyde anlamlı etkiler yaratır. Bireyi etkili dinleme, göz teması kurma, bireyi rahatlatma, bireyin sorumluluğunu alma, dokunma, duyarlı olma, saygılı olma, sözel güvenceler sunma, fiziksel ve zihinsel hazır bulunma, duygusal olarak açık ve ulaşılabilir olma, birey merkezli olma ve bilgi verme olarak tanımlanan bakım davranışları bireyde iyileştirici etki yaratır ve iz bırakır. Bu makalede bakımın iyileştirici etkisi yaşanmış bakım hikâyeleri ile tartışılmıştır.

Anahtar Kelimeler: Bakım hikâyeleri, bakım davranışları, hemşirelik, hemşirelik bakımı

ABSTRACT

Nursing care is a dynamic concept that shows continuous improvement. In the beginning, the concept of care encountered as a theoretical term becomes meaningful in terms of encountering and establishing relations with the patient in the clinic. Care can only begin when a nurse enters the living space and the existential space of the individual and thus the nurse detects the individual's (spirit) state, it feels and reacts. Each care behavior in interpersonal care creates meaningful effects on the individual. Care behaviors defined as effective listening, eye contact, individual relieving, take responsibility for the individual, touching, being sensitive, respectful, offering verbal assurance, physical and mental availability, being emotionally open and accessible, individual-centered and informing creates a healing effect in the patient and

\footnotetext{
*Süleyman Demirel Üniversitesi Sağlık Bilimleri Fakültesi, Hemşirelik Esasları, Isparta, Türkiye, E-mail: fadimetekin@sdu.edu.tr, Tel. 054381168 44, ORCID: https://orcid.org/0000-0003-0444-5843

** Akdeniz Üniversitesi Hemşirelik Fakültesi, Hemşirelik Esasları, Antalya, Türkiye,

E-mail: ekol@akdeniz.edu.tr, Tel. 050553947 29, ORCID: https://orcid.org/0000-0002-5124-6065

***Akdeniz Üniversitesi Hemşirelik Fakültesi, Doğum ve Kadın Hastalıkları Hemşireliği, Antalya, Türkiye, Tel. 053260357 91, ilkayarslan@akdeniz.edu.tr, ORCID: https://orcid.org/0000-0002-3529-9351 Geliş Tarihi: 11 Mayıs 2018, Kabul Tarihi: 19 Temmuz 2018

***Bu çalışma 7-9 Ekim 2016 tarihlerinde Ankara Üniversitesi Tıp Fakültesinde yapılan 5. Ulusal Geriatrik Hematoloji Kongresinde panel olarak sunulmuştur.

Atıf/Citation: Tekin F. G., Kol E., Boz I. Yaşanmış Bakım Hikâyelerinde İz Bırakan Eylemler: Analitik ve Yansıtıcı Bir Yaklaşım. Hacettepe Üniversitesi Hemşirelik Fakültesi Dergisi 2018; 5(3):..
} 
impacts a mark on the individual. This article discusses the healing effects of the care with care stories that have been experienced.

Key Words: Care stories, caring behaviors, nursing, nursing care

\section{GíRiş}

Bakım doğası gereği tanımlanması zor soyut bir kavramdır¹. Hemşirelerin bakım davranışları, bakım kavramına yeni anlamlar kazandırmaktadır. Günümüzde hemşirelik hizmetlerinde bakımın iz bırakan, etki yaratan ve iyileştiren bir eylem olduğu konusunda henüz net bir farkındalık gelişmemiştir. Dolayısıyla hemşirelik bakımı sadece teknik becerilerle sınırlı bir eylem olarak görülmektedir². Bakım, bakım davranışlarıyla görünür olmaktadır ${ }^{3}$. Bu makalenin amacı, yaşanmış hikâyelerde bakım davranışlarıyla verilen bakımın birey ve hemşirede bıraktığı izleri yansıtma yoluyla analiz etmektir.

\section{Bakım Kavramı}

Bakım Türk Dil Kurumu Sözlüğü’ne göre; bakma işi, bir şeyin iyi gelişmesi ve iyi durumda kalması için verilen emek, birinin beslenmesi, giyinmesi gibi gereksinimleri üstlenmek ve bunları sağlamak anlamına gelmektedir ${ }^{4}$. İsim olarak; ilgilenme, koruma, güvenliği sağlama, dikkat etme, endişe duyma, fiil olarak; önem vermek, sevgi duymak, ihtiyaçlarını karşılamak ve rahatlığı sağlamak anlamlarında kullanılmaktadır ${ }^{5-7}$.

Hemşirelik kuramcıları, bakımı hemşirelik paradigmasının en temel kavramı olarak değerlendirmiş ve bakımı hemşireliğin "çekirdeği” veya "özü” olarak tanımlamışlardır ${ }^{8-10}$. Leininger bakımı, bir insanın durumunu veya yaşam şeklini iyileştirmek, geliştirmek veya ölümle yüzleşmesi için belirgin ya da ön görülen ihtiyaçlarla birlikte başka bir insana veya topluma yardımcı olma, destekleme ve etkinleştirmeye yönelik eylemler olarak tanımlamaktadır ${ }^{8}$. Roach’a göre bakım basitçe duygusal ya da tutumsal bir müdahale değil; varoluşun, ilişki kurmanın ve ilgilenmenin toplamıdır. Aynı zamanda başka birine ya da kendine, bir düşünceye ve bir şeye olan bağlılığın kalitesidir; bakım zihin, akıl, irade ve duyguları içeren insanın kalbinden gelen bir yanıttır ${ }^{11}$. Swanson'a göre bakım insan onurunu korumak, insanlığ iyileştirmek ve insanları nesnenin ahlaki statüsüne indirmekten kaçınmaktır ${ }^{12}$. Bakımı insanlık onurunu koruma, iyileştirme ve geliştirme aracı olarak tanımlayan Watson'a göre bakım bir irade, amaç ve özveri haline gelmesi gereken bir değer ve tutumdur'. Bakım ancak hemşirenin bireyin yaşam ve varoluşsal alanına girmesiyle başlayabilir, böylece hemşire bireyin varoluş (ruh) durumunu saptar, bunu hisseder ve tepki gösterir. Böyle bir bakımda Watson, hemşire ve birey arasında öznel bir akış olduğunu ifade etmektedir ${ }^{13}$. Watson hemşirelik bakımının, bakım davranışlarının kullanılması ve bu davranışların bakım alanlar tarafından algılanmasıyla etkili olabileceğine inanmaktadır. Watson'ın tanımladığı bakım davranışları; dikkatli dinleme, göz teması kurma, bireyi rahatlatma, bireyin sorumluluğunu alma, dokunma, duyarlı ve saygılı olma, sözel güvenceler sunma, fiziksel ve zihinsel hazır bulunma, duygusal olarak açık ve ulaşılabilir olma, birey merkezli olma ve bilgi verme olarak sıralanabilir ${ }^{14}$. 
Özetle bakım, bireyin sorumluluğunu üstlenmek, ihtiyaçlarına yanıt vermek ve bireyi desteklemek üzere gerçekleștirilen eylemler sırasında fiziksel, zihinsel ve duygusal olarak varlığını ortaya koymak, bireyle birlikte olmaktır.

Bakım, uğraş alanının insan olması nedeniyle etik ve ahlaki boyutu olan sanatsal bir eylemdir'. Bu bakış açısıyla bakımın ortaya koyduğu eser "güzeldir" hatta "yücedir" ve hayranlık uyandırmaktadır. Hemşirenin bakım davranışları yoluyla gerçekleştirdiği bakım bireyde iz bırakarak iyileşmede olumlu bir etki yaratır. Johns'un aktarımına göre Boykin ve Schoenhofer; hemşirelik bakımıyla ortaya çıan güzelliklerin paylaşılmasının mesleki kimliğin sürdürülmesinde önemli rol oynadığını savunmaktadır. Ayrıca yaşanan deneyimlerin paylaşılmasındaki önemi şu ifadeyle vurgulamaktadır: "Hemşirelerin hikâyeleri doğal bir biçimde hemşireliğin özünü anlamamız için muhteşem bir kaynaktır. Hikâyeler bizlere hemşirelikte yaşanan durumların ortak noktalarını ve her birinin hem güzelliğini hem de eşsizliğini hatırlatır”15.

\section{Bakımı Görünür Kılmak, İz Bırakmak: Yaşanmış Bakım Hikâyelerinin Analizleri}

Bakım duyuşsal ve teknik beceriler olmak üzere iki temel bileşenden oluşmaktadır. Duyuşsal bileşende; güven oluşturma, duygu, inanç ve gerçeklerin kabulü, stres kontrolü, öğretme ve problem çözme yer alırken, teknik becerilerde; tedavi uygulama, invaziv girişimler ve uygulamalar yer almaktadır ${ }^{2}$. Bu iki bileşen bakım eylemlerinin görünür olması ve bakım alanda olumlu etki bırakması kapsamında temeldir. Verilen bakımın birey tarafından hissedilmesi, onda etki yaratması, görünebilir ve ifade edilebilir olması durumu Smith ve arkadaşları tarafından incelenmiştir ${ }^{10}$. Smith ve arkadaşları bu etkiyi; 1) insani bir gereksinim olarak bakım, 2) ahlaki bir zorunluluk ya da idea olarak bakım, 3) bir etki olarak bakım, 4) kişiler arası ilişki olarak bakım ve 5) terapötik müdahale olarak bakım olmak üzere beş boyutta değerlendirmişlerdir.

Bu makalede Smith ve arkadaşları (2013) tarafından tanımlanan beş etki boyutu temel alınarak, bakımın birey ve hemşire üzerindeki etkileri yaşanmış bakım hikâyelerinin analiziyle aktarılmıştır. Bakım hikâyelerinde, kullanılan isimler değiştirilerek birey ve yakınlarının onayıyla paylaşılmıştır.

1. İnsani bir gereksinim olarak bakım: Bakım doğuştan gelen insani bir gereksinimdir. Aynı zamanda bakım, insan doğasının bir parçası olan "varlık biçimi" dir ve insanın varlığını hissetmesi için bir zorunluluktur ${ }^{10}$. Aşağıda yazarların klinikte yaşamış olduğu bir "bakım ilişkisi" insanın en temel gereksiniminin karşılanmasıyla bakım alanda yarattığı etkiyi göstermek üzere paylaşılmıştır.

"Çalıștı̆̆ım yoğun bakım ünitesine kabul edilen 17 yaşındaki Bay İK, Parotis Ca tanısıyla opere edilmişti. İK’nın yoğun bir sekresyonu vardı, bu nedenle sik sık trakeostomi aspirasyonu gerekiyordu. Sekresyonu koyu renkte, yapışkan ve rahatsiz edici bir şekilde kokuluydu. IK aspirasyon için sık sık yatağın kenarına vurarak yardım istiyordu. Yanına gittiğimde gözümün içine, en derin bakışlarıyla baktığını görmek boğazımı düğümlemişti. Yüzümdeki ifadeyi anlamlandırmaya çalıştığın fark ettim. Acaba kokudan rahatsız olacağımı mı düşünüyordu? Yatağın kenarına oturarak İK'ya biraz daha yaklaştım: "Kokunun beni rahatsız edeceğini mi düşünüyorsun?" diye fısıldadım. İK başını sallayarak "Evet" yanitını verdi ve yüzünde büyük bir rahatlama ifadesi vardl. "O halde bizde maske 
takarız, hem de seni enfeksiyondan korumuş olurum" diyerek gülümsedim ve İK'nın biraz daha rahatlamasını sağladım. İK eliyle "Tamam" yanıtını verdi ve göz kırptı. Bunun üzerine tüm sekresyonu ve trakeostomi bölgesini temizledim. Ben bu girişimi yaparken gülümsüyor ve eliyle işlemi devam ettirmek ya da durdurmak için komutlar veriyordu. Bu davranışı onun kendi bakımına katılması için önemli bir başlangıçtı. Isslem tamamlanınca İK'ya sekresyonun temizlendiğini, artık rahatlıkla uyuyabileceğini, sekresyonun bir süre onu rahatsız etmeyeceğini, burada olacağımı ve olursa tekrar sekresyonu temizleyeceğimi söyledim. Sonrasında IK yaklaşık 4 saat kesintisiz rahat bir şekilde uyudu. Onun sekresyonu atamama ve solunum güçlüğü yaşama korkusu olmadan rahat bir şekilde uyuması hemşiresi olarak beni çok mutlu etmişti."

$\mathrm{Bu}$ bakım hikâyesinde hemşire en temel insan gereksinimi olan solunumun sürdürülmesine yönelik bakım girişiminde bulunmuştur. Hemşire, konuşmasa bile yüz ifadesi ve karyolanın kenarına vurmasıyla bireyin kendini ifade etme çabasını anlamış ve birey olarak varlığını kabul etmiştir. Bu düşünceyle bireyle arasında Watson'un tanımladı̆̆ı "bakım anı"nı yaşamış ve en belirgin biçimde; duyarlı olma, bireyi anlama, hazır bulunma, varlığını sunma ve onunla birlikte olma bakım davranışlarını kullanmıştır. Aslında hemşire kendi varlığını bireye hissettirdiği gibi bir birey olarak İK’nın da varlığını kabul etmiştir. Hikâyede sunulan bakımın bireyin rahatlamasında, oksijen gereksiniminin karşılanmasında ve uyku sürecinin tamamlanmasında iyileşmeye yönelik olumlu etki yarattı̆̆ı söylenebilir.

2. Ahlaki bir zorunluluk olarak bakım: Bakım hemşirelikte temel bir değer veya bireyin sorumluluğunu almak olarak tanımlanır ${ }^{10}$. Florence Nightingale de hemşireliği ve bakımı "bireyin sorumluluğunu almak" olarak tanımlamaktadır ${ }^{16}$. Bu tanım sorumluluğunu birey için ihtiyacı olan şeyleri düşünmek, onu potansiyel tehlikelerden korumak olarak bakımın ahlaki boyutunu daha açık bir şekilde ortaya çıkarmaktadır. Hemşirelik bakımını ayrıcalıklı kılan özellik; bakımın hem ahlaki hem de duyuşsal yönlerinin profesyonel bilgi ve becerilerin bir araya getirilerek hemşire ve birey ilişkisine yansıtılmasıdır ${ }^{1}$. Aşağıda verilen bakım hikâyesi, bakımının ahlaki boyutunu somutlaştırmak üzere paylaşılmıştır.

"Kadın hastalıkları ve doğum kliniğinde yatan AS’nin odasına girdiğimde kendisinin yüzünde ăgrı/acı çeken bir ifade gördüm. AS pencere kenarındaki yatakta yatıyordu, yanındaki yatakta ise sezaryen operasyonu geçirmiş başka bir hasta vardi. Sezaryen sonrası ikinci gününde olan anne bebeğini emzirirken ona güzel sözler söylüyor ve şarkı mırıldanıyordu. Bir an için anne ve bebeğiyle ilgilenmek ve bir hemşire olarak onlara bakım vermek istedim. Ancak AS, onlara ve bana bakıyor, anlamsiz sesler çıkarıyor ve zorlanarak yüzünü bana doğru çevirmeye çalışıyordu. O an AS’nin bana bakması, ses çıkararak yardım istemesi ve bu konudaki çabası, içimde bir burukluk yaratmış ve beni öncelikli olarak onun yatağına yöneltmişti. Aslında anne ve bebekle ilgilenmek benim için daha mutluluk verici duruyordu ama AS'nin yanına gitmekten kendimi alamadım. Yanına gittim, yatağına oturdum, elini tuttum ve gülümsedim. AS de gözlerini kapattı, ses çıkarmayı bıraktı ve gülümsedi. Yatağın içinde yan yatıyordu, supine pozisyonu almaya çalışıyor ancak alamıyordu. Çarşafı biraz çekip sırt bölgesine ve vücuduna baktığımda "Bugün öğleye kadar AS ile birlikteyim" diye düşündüm. Sırt bölgesinde iki skapula arasında büyük bir kitle vardı ve supine pozisyonunda yatamıyordu. Sürekli lateral pozisyonda olduğu için ikinci evre basınç ülseri gelişmişti. 
Batında kitle tanısıyla hastanede yatıyor ve yoğun solunum sıkıntısı yaşıyordu. Batındaki kitle inspeksiyonla doğrudan gözlemlenecek kadar büyüktü. AS’nin 28 yaşında olmasına rağmen hem büyüme geriliği hem de mental retardasyonu vard, kendini ifade edemiyor sadece anlamsız sesler çıkartıyordu. Yaklaşık 10 dakika onunla kalıp gereksinimlerini değerlendirdim ve onunla konuşarak güvenini kazanmaya çalıştım. Sonrasında banyo ihtiyacını karşıladım, basınç ülseri bulunan bölgenin bakımını yapıp destekle fowler pozisyonu verdim ve hem sirt bölgesini hem de solunumunu rahatlattım. Aramizdaki iletişime ve bakıma annesi de katılmıştı. Odasından ayrılırken annesi "Size minnettarım, ancak AS sizi asla unutmayacak biliyorum. Ĕger şu anda izin verirseniz sizi öpmek istediğini ifade ediyor" dedi. Geri dönüp isteğini karşılamasına izin verdiğimde yaptıklarımın ona ve bana iyi geldiğini fark ettim.”

$\mathrm{Bu}$ bakım hikâyesinde hemşire sezaryen sonrası anne ve bebeğin bakımına katılmak istese de, AS’nin bir birey olarak bakım almada öncelikli olduğunu, kendisinin de ahlaki boyutta ona bakım verme yükümlülüğünün bulunduğunu kabul etmiştir. Etkili bir iletişimle "bakım anı"ndaki iletişimi başlatarak AS’nin kendisini ifade etmesini sağlamıştır. AS’ye uyguladığı bakımla onu rahatlatmış ve ağrı/acısını gidermiştir. Bu etkileşimden kendisi de bir hemşire olarak doyum sağlamış ve hemşirelik mesleğini yaptığı için mutluluk duymuştur. Hemşire burada en belirgin biçimde; duyarlı olma, bireyle birlikte olma, bireyin sorumluluğunu alma, bireyi rahatlatma, duygusal olarak açık ve ulaşılabilir olma bakım davranışlarını kullanmıştır. Aktarılan bakım hikâyesi, Boykin ve Schoenhofer'ın ${ }^{17}$ belirttiği "Bakım için gerçekten zaman var mı?" makalesindeki hikâyeyle kendini ifade edemeyen bireylerin bakım gereksinimlerini dikkate alma boyutunda ve ahlaki bir zorunluluk olarak bakımı yerine getirmede benzerlik göstermektedir.

3. Bir etki olarak bakım: Smith, bakımın etkisinin duygusal olarak bakım alana katılmaktan ve onunla empatik bir deneyimin paylaşımından kaynaklandığını vurgular ve bu birlikteliğin hem bakım alan hem de bakım veren bireyi mutlu ettiğini belirtir ${ }^{10}$. Nitekim Watson İnsan Bakım Kuramı’nda bakımın hemşireyi ve bireyi karşılıklı etkilediğini sıklıkla vurgulamaktadır ${ }^{13,14}$. Aşağıda verilen hikâyede hemşireyle birey arasında karşılıklı etki bırakan bir bakım ilişkisi yaşanmıştır.

“Bayan NS'yi trafik kazasına bağlı torakal vertebra fraktürü nedeniyle yoğun bakım ünitesine kabul ettiğimde bilinci açıktı. NS sık sık çocuklarının durumu konusunda yoğun kaygı yaşadığını belirtiyordu. Yaşam bulguları normal değerlerdeydi, torakal vertebranın korunması için omurga stabilizasyonu gerekiyordu. NS, herhangi bir fiziksel şikâyet belirtmiyor, ancak tekrarlı bir biçimde çocuklarını soruyordu. Hasta kabulü sonrası hekim vizitinde torakal 6-12. vertebrada fraktür olduğunu ve alt ekstremitelerde geri dönüşümsüz parapleji geliştiğini duyduğumda iki küçük çocuğu olan ve hemen iyileşip ertesi gün taburculuğunu bekleyen 28 yaşındaki genç anne bu kayıla nasıl baş edecek diye düşündüm. Kendimi onun yerine koyduğumda; bu durumla baş etmek benim için imkansızdı ve bu halde ona yardım etme gücüm oldukça düşüktü. Mesaide görevli hekim arkadaşım da benimle aynı durumdaydı ve ikimiz de NS'ye yardım etme konusunda güç oluşturmak gerektiğini biliyorduk. Ancak göz yaşlarımıza hakim olamıyor, onun odasına gitmekte zorlanıyorduk. Zor olsa da birlikte NS'nin yanına gidip yardım edebilmek amacıyla onu dinledik ve kendisini tanımaya, anlamaya çalıştık. NS, "Halime bin kere şükür can kaybı olmadan atlattık kazayı, biraz ayaklarım uyuşuk ama 
önemli değil, çocuklarımın sağlıklı olduğunu öğrendim, bu bana yeter. Buradan evime gider gitmez dua edip evimde Kuran okutacağım...” dedi. Ancak bir saat sonra beyin cerrahi hekimiyle görüşmesinden sonra sürekli paraplejik kalacağını öğrendiğinde, "Bu imkansız!!!!” diyerek bağırmaya, kollarını karyolanın kenarlarına vurmaya başladı. Yaklaşık 10 dakika hıçkırıklarla ă̆ladı... Aynı noktaya bakarak bir süre bekledi ve tekrar ağladı... Sonra çocuklarını görmek istedi, geldiklerinde onları ağlayarak kucakladı ve konuşamad. Hekim ve ben NS ile planlı üç görüşme yaptık, önce durumunu kabul etmesine yardımo olduk. Son görüşmede NS bana dönerek evine gittiğinde tekerlekli sandalyeyle mutfakta nasıl işyapabileceğini sordu. Bu bizim için ümit verici bir soruydu ve ev ortamının hazırlı̆̆ı konusunda eşiyle planlamalar yaptık. Bu gelişmeler NS kadar beni de rahatlatmıştı, ben de durumu kabullenip iyileşme planlarına katılmıştım. NS taburcu olduktan altı ay sonra yoğun bakım çalışanları için evinde bir yemek daveti gerçekleştirdi. Bizi karşıladığında ilk söylediği "Bütün yemekleri kendim yaptım, sayenizde hayata döndüm” ifadesi olmuştu. Onu tekerlekli sandalyeye bağıml yeni yaşamında mutlu görmek bizi de güçlendirmişti."

Bakım hikâyesinde hemşire ile hekim durumu kabul etme konusunda zorlanmış ve birlikte görüşme yaparak kendilerini güçlü hissetmek istemişlerdir. Kadını uzun süre aktif biçimde dinleyerek güven sağlamışlar ve onun gelecekle ilgili planlamalarına katılmışlardır. Kadını evinde iyi görmek onlara da iyi gelmiştir. Hemşire bu bakım hikâyesinde en etkili biçimde; duyarlı olma, empatik düşünme, etkili dinleme, bireyi anlama/tanıma ve bireyle birlikte olma bakım davranışlarını kullanmıştır. Yaşanan bakım ilişkisi hem bakım alan hem de bakım veren bireylere iyi gelmiş ve bir iz bırakmıștır.

4. Kişiler arası ilişki olarak bakım: Bakım, birey ve hemşire arasındaki ilişki sırasında ortaya çıkan duygu ve davranışları kapsamaktadır ${ }^{10}$. Bakım; uzmanlık, kişilerarası duyarlılık ve samimi ilişkilerle karakterize kişilerarası bir süreçtir ${ }^{18}$. Watson bakımın yalnızca kișilerarası ilişkiler yoluyla etkili bir șekilde gösterilip uygulanabileceğini belirtmektedir ${ }^{13}$. Bu bakım hikâyesinde bașlangıçta sözel olmayan bir bakım ilișkisi kurularak bireye etkili bir bakım verilmeye çalışılmıştır.

"Yoğun bakım ünitesine 24-08 mesaim için geldiğimde izole odada çenesine kadar çarşafla kapatılmış, oldukça ödemli bir yüze sahip olan Bayan AÖ’yü teslim aldım. Oda soğuk ve monitörün alarm sesi oldukça yüksekti. Monitör alarmını ayarladım, oda ısısını biraz artırarak hastamın başucuna yaklaştım. Aslında AÖ uyanıktı ama iletişim kurmamak için başını bile hareket ettirmeden gözleri kapalı bir şekilde yatıyordu. AÖ, Meme Ca tanısıyla terminal dönemde takip edilmekteydi. Başucunda biraz bekledim, yanında biraz daha kalmak ve orada bulunduğumu kendisine hissettirmek için yaşam bulgularını kaydedip ilaçlarını kontrol ettim, dosyasını inceledim, fakat AÖ benimle iletişim kurmamakta kararlıydı. Çarşafı biraz açıp elini tuttum, eli çok soğuk ve ödemliydi, elini iki avcumun içine alarak ısıtmaya çalıştım ve bekledim, başını hafifçe çevirdi ve gözlerini araladı. Kendimi tanıttım ve sabaha kadar onun yanında olacağımı söyledim. Ona baktım, hafifçe gülümsedim. Kendisine benden istediği bir şey olup olmadığını sordum. Gözlerini hafifçe araladı ve bekledi... Benim kendisine bakım verme konusunda ne kadar güvenilir ve kararlı olduğumu test ettiğini hissettim. Ona doğru biraz daha eğildim, kendisine yakın olmak istedim. Kısık sesle "Kızım..." dedi, "Kızımı keşke görebilsem” diyebildi güçlükle. Bu isteği çok içtendi ve karşılamak istedim, 
ancak kızı çok küçüktü, geceydi ve hastaneye çocuk ziyaretçi alınmazdı. AÖ belki de son saatlerini yaşıyordu, solunumda gittikçe zorlanıyordu ve bu anlarında kızını görmesi kadar insancıl bir ihtiyaç olamazdı. Tüm prosedürleri tamamladıktan sonra sabah saat 07.30 da AÖ'nün kızıyla buluşmasını sağladım. Bu buluşma sırasında sorumlu hemşire, hekim, AÖ’nün eşi ve hastanenin psikoloğu da vardı. Oldukça duygusal geçen buluşma sonrasında AÖ’nün rahatladığı beden dilinden anlaşılıyordu. AÖ, yaklaşık dört saat sonra yaşamını yitirdi. Aradan yedi yıl geçmesine rağmen bu bakım ilişkisinin etkisini halen yaşıyor olmam, AÖ’nün eşinin belirli aralıklarla beni arayıp kızı ve kendi yaşamlarıyla ilgili paylaşımda bulunması, benimle AÖ’yü anması bu bakımın benim ve onlar için iz bırakan bir eylemin göstergesi olduğunu düşündürmektedir.”

Hikâyesinde hemşire dikkatli gözlem yeteneğiyle bireyin içinde bulunduğu durumu anlamıştır. Odada bir süre beklemesi, gürültüyü azaltması, oda ısısını ayarlaması ve kendini tanıtarak bireye zaman tanımasıyla AÖ’nün varlığını bir birey olarak kabul etmiş ve beden diliyle verdiği mesajları da dikkate alarak etkili bir iletişim başlatmıştır. Burada hemşire AÖ’ye fizikötesi varlığını sunmuştur. Fizikötesi varlık; kapsamı daha geniş ve soyut olan bir varlık biçimidir, fizikötesi varlık ortamında enerji değişimi olur ve daha manevidir. Birey ve hemşire fiziksel olarak oradadır, enerji etkileşimi iki kişinin ötesine gider ve çevreye yayılarak başkaları tarafından hissedilir. Fizikötesi varlık bireyler tarafından huzurlu ve rahatlatıcı olarak hissedilir ${ }^{19,20}$. Bakım hikâyesinde hemşire bakım alanla bir enerji alanı yaratmış, ona güven vermiş ve onun gereksinimini anlayarak karşılamıştır.

5. Terapötik müdahale olarak bakım; Hemşireliğe ve bakıma özgü davranışlardan özenli dinleme, varlığını hissettirme, bireyle birlikte olma, bilgi verme, açık olma, bireyin savunuculuğu ve teorik yetkinliği kullanabilme bireyi iyileştiren terapötik yaklaşımlardır ${ }^{10}$. Hemşireyle birey arasındaki terapötik bakım ilişkisi aşağıdaki bakım hikâyesinde paylaşılmıştır

"E.H, 25 haftalık prematür bir bebeği olduğunu, durumu hala kabullenemediği için bebeğini görmek istemediğini, yenidoğan yoğun bakım ünitesinden anneyi aramalarına rağmen hiç gitmediğini öğrenmiştim. E.H, postoperatif 3. günde olmasına rağmen bebeğini görmek istememişti. Odasına bebeğini neden görmek istemediğini anlamak için görüşme yapmaya gittiğimde, annenin duygusal olarak kötü durumda olduğunu gördüm ve yanına oturdum. Anne sürekli ağlıyordu... Yenidoğan yoğun bakım ünitesinden getirdiğim ve bebeğin kokusundan annenin etkileneceğini düşündüğüm giysileri E.H’ye gösterdim. Ancak bebeği görmek istemesi konusunda bir ilerleme sağlayamadım. Ertesi gün bebeğin durumunun kötüye gittiğini öğrendim ve "Bu bebeğin annesine ihtiyacı var, o olmadan iyileşemeyecek ve annesi onu bir kez bile görmedi. Bebeğini kaybederse onu görmeye gitmediği her an için pişman olacak ve çok üzülecek” diye düşündüm. Bu endişelerim ve öfkem yüzünden soluğu E.H’nin odasında aldım. Biraz sert bir tonla "Bebeğinizin durumu iyi değil, onun güçlenmesi ve hayata minik elleriyle tutunabilmesi için sizin varlığınıza ihtiyacı var” dedim. Bunun üzerine E.H, bebeğini görmek üzere gideceğini ifade etti. Belki bunu yapmam yanlıştı, ama yapmak zorundaydım. Sonunda anne bebeğini görmeye gitti ve o andan itibaren yanından ayrılmak istemedi. E.H’nin gerçekleri görebilmesi ve durumu fark edebilmesi için itici bir güce ve cesarete ihtiyacı vardı. Bana göre bu konudaki kararlı davranışlarım E.H için terapötik bir müdahale sayılırdı...” 
Bu bakım hikâyesinde hemşire, anne ve bebeği arasında ilişki kurarak bir birliktelik yaşamış ve duygusal olarak annenin/kadının bakımına katılmıştır. Watson’ın İnsan Bakım Kuramında tanımlanan kişilerarası bakım ilişkisi açık bir şekilde uygulanmıştır ${ }^{14}$. Hemşire bakımın bütüncüllüğünü, yenidoğan için oldukça önemli olan aile merkezli bakımı göz önünde bulundurarak anneyi bakıma dahil etmeye çalışmıştır. Bunun için öncelikle hemşire annenin yanında olarak yaşadığı durumla ilgili olumlu ve olumsuz duygu ve düşüncelerini ifade etmesini desteklemiştir. Ardından anneyi bebeğinin yanına gitmek ile ilgili düşüncelerini açıklaması için cesaretlendirmiştir. Burada hemşire ayrıca bebeğin kıyafetlerini annesine gösterip onun durumunun ciddiyeti hakkında bilgi vererek anne ve bebeğin ilk karşılaşma anı için destek olmuştur. Hemşire belirgin biçimde; duyarlı olma, empati kurma ve bireyin sorumluluğunu alma bakım davranışlarını kullanmıştır. Hikâyedeki bakım ilişkisi, anne-bebek ilişkisinin sürdürülmesi ve bebeğin iyileşmesinde terapötik bir girişim olarak yorumlanmıştır.

Verilen bakım hikâyelerinden anlaşılacağı üzere bakım, hemşireliğin bilinmeyen ve örtülü bir bileşenidir ${ }^{21}$. Görünen hemşirelik bakımı; bakım anında kullanılan beden dili, dokunma, jest ve mimikleri kapsar ${ }^{22}$. Swanson'a göre görünen bakım; bilmek, bireyle birlikte olmak, birey için yapmak, etkinleştirmek ve inancı sürdürmekle mümkündür ${ }^{23}$. Baggio ve Erdmann ise bakımın görünürlügüünün hemşire-birey arasındaki etkileşimlerde ve bu etkileşimler sonucunda görülen değişimlerde ortaya çıkacağını savunmaktadır ${ }^{24}$. Görünen ve görünmeyen bakım konusunda hemşire ve bireylerin görüşlerine ilişkin yapılan bir çalışmada bakımın "hemşirenin yapmış olduğu bir hareket ya da jest ve mimik, hastaya göstermiş olduğu ilgi ve dikkat, ayrıca hemşirenin beceri düzeyi” ile görünür kılınabileceği belirtilmektedir ${ }^{22}$. Bakım alanların hemşirelik bakımında şefkat deneyimleri ve bakımı nasıl algıladıklarını anlamak için yapılan bir çalışmada, hemşirelerin şefkat göstermek için yeterli zamanlarının olmadığından şikâyet ettiklerini fakat kısa sürede bakım alanlarda küçük ama önemli değişimler oluşturdukları belirtilmektedir ${ }^{25}$. Yapılan bu çalışma sonucunda üç ana tema ortaya çıkmıştır. (1) bakım alanlar 'şefkati', kendilerine zaman ayrılması ve anlaşılmak, (2) 'şefkatin etkisini' hemşirelerin kendisini bakım alanın yerine koyması, (3) 'daha fazla şefkat göstermeyi’ de hemşireliğin özü ve iletişim olarak adlandırmışlardır. Ayrıca bazı bakım alanların ifadeleri şöyledir; "Hemşireler benimle göz teması kurdular, bana dokundular ve ellerini omuzlarımın üzerinde hissettirdiler. Bu hareketler hastalara aynı zamanda bir insan oldukların hissettirir. Biliyorum hemşireler çok meşguller ama yaptıkları bu küçük ayrıntılar bize vermiş oldukları bakımın bir göstergesidir”.

\section{Klinik Uygulama İçin Öneriler}

Bakım davranışları maliyet ve zaman gerektirmeyen, kolay uygulanabilen ve sonuçta bakım alanın iyileşmesinde en az ilaç kadar etkili eylemlerdir. Üstelikbakım davranışları yolu ile bireyin rahatlatılması ve iyileşme süresindeki kısalma hemşire için zaman kazandırıcıdır. Bu nedenle klinikte çalışan hemşirelere bakım davranışları eğitiminin verilmesi ve bakım davranışlarının bakıma yansıtıldığı bir kültür oluşturulması kurumlar için bir gerekliliktir. 


\section{SONUÇ}

Sonuç olarak bakımın görünebilir ve iz/etki bırakan bir eyleme dönüşmesi hemşirenin gösterdiği bakım davranışlarına bağlıdır. Makalede paylaşılan bakım hikâyeleri ve araştırma sonuçlarında da görüldüğü üzere bakım davranışları ancak hemşire ve hizmet sunduğu birey arasındaki "Bakım Anı" ve "Kişilerarası Bakım İlişkisi” ile başlayıp sürdürülebilir. Dahası bakım davranışları ve bakım ilişkisi sadece hizmet sunulan bireyde değil hemşirenin kendisinde de etki yaratıp iz bırakmaktadır.

\section{KAYNAKLAR}

1. Dinç L. Bakım kavramı ve ahlaki boyutu. Sağlık Bilimleri Fakültesi Hemşirelik Dergisi, 2010; 74-82.

2. Birimoğlu C, Ayaz S. Hemşirelik öğrencilerinin bakım davranışlarını algılamaları. Hacettepe Üniversitesi Hemşirelik Fakültesi Dergisi, 2015; 40-48.

3. Arslan-Özkan İ, Okumuş H. Bakım ve iyileşmenin kesiştiği bir model: watson’ın insan bakım modeli. Hemşirelikte Araştırma Geliştirme Dergisi, 2012; 14 (2):61-72.

4. T.C. Başbakanlık Atatürk Kültür Dil ve Tarih Yüksek Kurumu Bakımın Tanımı. URL: http://tdk.gov. $\operatorname{tr} /, 14.10 .2017$.

5. Cutcliffe JR, McKenna HP. The Essential Concept of Nursing. 1st Edition. China: Elsevier Churchill Livingstone; 2005. p. 37.

6. English Oxford Living Dictionaries Definition of Care. URL: https://en.oxforddictionaries.com/, 23.11.2017.

7. Cambridge Dictionary Definition of Care. URL: https://dictionary.cambridge.org, 23.11.2017.

8. Leininger MM. Caring An Essential Human Need: Proceedings of the Three National Caring Conferences. United States of America: Wayne State University Press; 1988.

9. Watson J. Nursing Human Science and Human Care: A Theory of Nursing. United States of America: National League for Nursing Press; 1999.

10. Smith MC, Turkel MC, Robinson-Wolf Z. Caring in Nursing Classics: An Essential Resource. United States of America Springer: Publishing Company; 2013. p. 8-42.

11. Roach M. Caring from the Heart: The Convergence of Caring and Spirituality. United States of America: Paulist Press; 1997.

12. Swanson KM. Providing care in the NICU: sometimes an act of love. Advances in Nursing Sciences, 1990; 13 (1):60-73.

13. Watson J. Caring theory as an ethical guide to administrative and clinical practices. Nursing Administration Quarterly, 2006; 30 (1):48-55.

14. Watson J. Nursing: The philosophy and science of caring. United States of America: University Press of Colorado; 2008.

15. Johns C. Reflective practice: Revealing the (he)art of caring. International Journal of Nursing Practice, 2001; (7):237-245.

16. Nightingale F. Notes on Nursing: What it is and what it is not. London: Harrison and Sons; 1860.

17. Boykin A, Schoenhofer SO. Invest in yourself. Is there really time to care?. Nursing Forum, $2000 ; 35$ (4):36-38.

18. Finfgeld-Connett D. Meta-synthesis of caring in nursing. Journal of Clinical Nursing, 2008; (17):196204. 
19. Easter A. Construct analysis of four modes of being present. Journal of Holistic Nursing, $2000 ; 18$ (4):362-377.

20. Osterman PA. A Participant Observation Study of Experienced Nurses' Presence in Daily Care. University of Rhode Island 2002.

21. Milligan C, Wiles J. Landscapes of care. Progress in Human Geography, 2010; 34 (6):736-754.

22. Canzan F, Heilemann MV., Saiani L, Mortari L, Ambrosi E. Visible and invisible caring in nursing from the perspectives of patients and nurses in the gerontological context. Scandinavian Journal of Caring Science, 2014; (28):732-740.

23. Swanson KM. Caring made visible. Creative Health Care Management, 1998; 1-18.

24. Baggio MA, Erdmann AL. The (in)visibility of caring and of the profession of nursing in the relations space. Acta Paulista de Enfermagem, 2010; 23 (6):745-750.

25. Bramley L, Matiti M. How does it really feel to be in my shoes? Patients' experiences of compassion within nursing care and their perceptions of developing compassionate nurses. Journal of Clinical Nursing, 2014; (23):2790-2799. 